\title{
Effects of feeding rice gruel based milk replacer on growth, carcass characteristics and rumen development of goat kids
}

Islam MA, MB Sarker, A Khatun, MR Amin and M Moniruzzaman*

Department of Animal Science, Bangladesh Agricultural University, Mymensingh- 2202, Bangladesh

\begin{abstract}
Supplementation of concentrate feed during late pregnancy of doe is an approach to improve milk yield and kid performance after kidding. The experiment was conducted to find out appropriate level and duration of supplementation to the pregnant doe. The data of the experiment were analyzed applying Completely Randomized Design (CRD) with factorial arrangements with three replications. First factor used in the experiment was the duration of concentrate feeding (15 days, 30 days, 45 days and 60 days) and second was amount of concentrate supplemented $(2.00 \%, 1.75 \%, 1.50 \%$ and $1.25 \%$ of their body weight). Birth weight, weaning weight, milk yield and kid mortality in different groups were recorded. Birth weight and weaning weight were found higher in 60 days supplemented group i.e. $2.3 \pm 0.23 \mathrm{~kg}$ and $10.94 \pm 0.41 \mathrm{~kg}$, respectively. Both birth weight and weaning weight were also found higher with 2 percent concentrate feeding group than others i.e. $2.1 \pm 0.23 \mathrm{~kg}$ and $9.64 \pm 0.42 \mathrm{~kg}$, respectively. Milk yield recorded for fourth week shows that higher milk yields were found in 2 percent concentrate supplemented group with 60 days time period. The result showed that by increasing the level of concentrate during late gestation period of does increased the birth weight, weaning weight of kids and increased milk yield of does. So the higher level of concentrate supplementation is required during 45 to 60 days of late gestation in does.
\end{abstract}

Key words: Artificial feeding, Goats, Growth, Kids, Rice-gruel, Milk replacer

\section{Introduction}

A high level of kid mortality is a significant barrier to increasing goat production in tropical countries. Insufficient milk produced by their dam is considered a major cause of higher kid mortality in Black Bengal goats. For this reason, artificial feeding is required to prevent kid mortality. Milk is a unique food for young mammals that contains a lot of essential nutrients for their normal development. However, milk is an expensive human food. So, other food items are required to be included as a substitute of milk in the diets of goat kids. It is difficult to find an acceptable alternate to milk protein. Terui et al. (1996) demonstrated that wheat gluten can replace milk protein up to $50 \%$ in milk replacer without compromising the growth of calves. Akinyele and Harshbarge (1983) conducted an experiment to evaluate soybean protein as protein source in calf milk replacers and concluded that calves were able to use soy-based milk replacers more effectively. Ghorbani et al. (2007) suggested that soymilk might be offered as a milk replacer during the first $2-3$ week of age in calves. Previously we reported that whole milk could be replaced by soymilk up to $50 \%$ without significant effects on growth, carcass characteristics, rumen, and gonad development of Black Bengal kids (Sarker et al., 2015).

An ideal milk replacer not only supports the growth but also provides sound health for infants. Blood parameters are good indicators of the health and immune status of young kids. According to Swenson (1970) nutrition affects the blood values of animals. Blood profile is influenced by diet in domestic species (Oyawoye and Ogunkunle, 2004; Iheukwumere and Herbert, 2002). According to Isaac et al. (2013) haematological components including RBC, WBC and $\mathrm{Hb}$ are valuable indicators to understand the toxicity, especially, with feed constituents that affect the physiological and health status of animals.

Neonatal kids are functionally monogastric like pigs and humans. They are termed as preruminants. At this stage, all four compartments of ruminant stomach except abomasum are nonfunctional, undeveloped, and small in size and disproportionate to the adult digestive system (Tamate et al., 1962). The rumen of the neonatal occupies about $25 \%$ volume of the whole stomach (Sato et al., 2010). The rumen

*Corresponding author: monir.as@bau.edu.bd 
only starts to grow at 2-3 weeks of age and growth will continue until about 2-3 months of age. In young goats, the suckling reflex triggers the oesophageal groove to close so that milk bypasses the rumen and flows directly in to the abomasum where digestion occurs. However, faster rumen development is desirable as it has synergistic effects on growth (Quigley et al., 1991). When the young goat's starts to eat solid foods, these feeds stay in the rumen and lead to development of the microbial population. This change from pre-ruminant to ruminant is a gradual process.

It is known that rice gruel is usually produced as a by-product of cooking rice in rural households in south Asian countries.It might be offered to ruminants as a source of soluble carbohydrate, similar to molasses (Hasanuzzaman et al., 2014). Rice gruel is fedto dairy and fattening cattle in Bangladesh (FAO, 1999). Cattle are often offered rice gruel mixing with rice bran and vegetable scraps in India (Suresh et al., 2016). Information regarding the effects of feeding rice gruel on the performance of infant animals are limited. In the present study, soy flour was added to rice gruel and mixed with cow milk in different proportions to prepare milk replacers. Finally, the effects of rice-gruel based milk replacers on growth,carcass characteristics and development of rumen was examined.

\section{Materials and Methods}

\section{Animals and management}

Fifteen male Black Bengal goat kids of 2-3 weeks old were divided into three groups (Group A, B and $C$ ) that were similar in initial live weight, litter size of their dam, parity and dam's live weight. Each group consisted of five kids. They were fed individually on different milk treatments (A - 100\% whole milk, B - 75\% whole milk + $25 \%$ rice-gruel milk and C - 50\% whole milk + $50 \%$ rice-gruel milk). The three groups of kids were housed in 3 separate pens. In each pen, 5 kids were kept. The floor space per kid was 1.7 $\mathrm{m}^{2}$. The house was well ventilated. Every day the floor, feeder and water trough were cleaned using phenyl as antiseptic. Separate feeders were used for roughage and concentrate feeding.

Kids were fed thrice daily up to 8 weeks old and received a total quantity of milk replacer up to $10 \%$ of their live weight per day. From 9 to 11 weeks old, kids were fed twice daily receiving a daily total equal to $1 / 15$ th live weight. Thereafter, the amount of milk replacer was reduced to $1 / 25$ th live weight fed once daily up to 14 weeks old. Gradually the amount of milk replacer was reduced to zero by the end of week 13.In addition to whole milk and rice-gruel based milk replacer, all the kids were fed concentrate mixture (24\% crude protein) and green grasses ad libitum basis. This study was approved as ethically sound by Bangladesh Agricultural University Research System (BAURES).

\section{Preparation of rice-gruel milk and milk replacer}

Rice-gruel was prepared by boiling rice grain following the traditional method. Whole soybean, free from immature grain, field damage and black spot, were ground to produce soy flour. An amount of $125 \mathrm{~g}$ powder was dissolved with 1000 $\mathrm{ml}$ of rice-gruel by stirring. Thereafter, it was boiled at $100^{\circ} \mathrm{C}$ for $10-15$ minutes with constant stirring. After cooling, rice-gruel in combination with whole milk was supplied to the kids as milk replacer. The rice-gruel milk was mixed with whole milk according to the stated experimental design. The required amount of cow milk was collected from a local dairy farm. Milk was filtered, boiled and fed to kids after cooling. Milk, rice-gruel and milk replacers were analyzed to determine the dry matter, fat, protein, lactose, ash and solids-not-fat (SNF) content by using the procedure described by Aggarwala and Sharma (1961) and AOAC (1984). Comparative chemical composition of milk, rice gruel and milk replacers are shown in Table 1.

Table 1. Chemical composition of whole milk, rice gruel and rice gruel based milk replacers

\begin{tabular}{lcccc}
\hline $\begin{array}{l}\text { Constituents } \\
\text { (g/kg; fresh basis) }\end{array}$ & Whole milk & Rice gruel & $\begin{array}{l}\mathbf{7 5 \%} \text { whole milk+ } \\
\mathbf{2 5 \%} \text { milk replacer }\end{array}$ & $\begin{array}{l}\mathbf{5 0 \%} \text { whole milk+ } \\
\mathbf{5 0 \%} \text { milk replacer }\end{array}$ \\
\hline Total solids & 132.5 & 119 & 146.2 & 122.7 \\
Fat & 49 & 32 & 43.5 & 37.5 \\
Protein & 30 & 40 & 32.5 & 35 \\
& & & & 35
\end{tabular}




\section{Live weight}

Each kid was weighed weekly at 8.00 am using a digital balance (T-Scale, Taiwan). The kids were kept off feed overnight (12hrs) before weighing.

\section{Collection and processing of blood}

Blood samples were collected via jugular vein puncture into evacuated tubes containing Ethylene di amine tetraacetic acid (EDTA) for determination of blood components such as RBC, WBC, $\mathrm{Hb}$ and PCV.

\section{Carcass and non-carcass characteristics}

Live weight ( $L W)$, length of body $(B L)$, heart girth (HG), circumferences and length of neck (NL), and height at withers $(\mathrm{WH})$ of each kid were recorded prior to sacrifice. Kids were fasted overnight and sacrificed using the approved "Halal" method. By this method, goats were bled by cutting the throat and then slaughtered by severing the head at its articulation on the occipito-atlantal space. At the time of sacrifice, blood was collected in a pail and weight was recorded. The head was removed along with the pelt and feet, and each weighed individually. The length, width and thickness (at butt, belly and shoulder) of skin were recorded. The digestive tract was removed and weighed full and empty to obtain the weight of the "gut fill". Liver, kidney, spleen, lungs with trachea, heart, caul fat and renal fat were separated from attached tissue and weighed separately. Warm carcass weight was recorded immediately after completing dressing and evisceration. Finally, the longisimusdorsi muscle was collected to determine chemical composition of meat by proximate analysis (AOAC, 1984).

\section{Rumen development}

After slaughter, reticulo-rumens were harvested, emptied and rinsed with cold water. Those were then transported immediately to the laboratory. Rumen tissues were sampled from nine different positions. These were right side of cranial ventral sac (RD), Left side of cranial ventral sac (LD), right side of cranial dorsal sac (RC), right side of caudal dorsal sac (RB), right side ventral portion of caudal ventral blind sac (RE), left side ventral portion of caudal ventral blind sac (LE), left side of cranial dorsal sac (LC), left side of caudal dorsal sac (LB), caudal portion of the caudal ventral blind sac (A) (Lesmeister et al., 2004 and Sarker et al., 2015). The thickness of the rumen was measured at each of these sites. To determine papilla density, the number of papillae per microscopic field was assessed at $5 \times 10 \mathrm{X}$, and visual observations were taken using a Stereo Zoom microscope (CZM6: Labo America Inc., California, USA) at the nine different sites.

\section{Histology}

Rumen tissues from nine different sites, were fixed in Bouin's solution for subsequent measurement of rumen papilla length and width. After dehydration and cleaning, tissues were infiltrated and embedded with melted paraffin. Five $\mu \mathrm{m}$ thick sections were prepared by using a rotatory microtome and placed upon glass slides and air dried. The sections were then stained with haematoxylin and eosin. Finally the stained sections were permanently mounted with a cover slip using DPX (Merck Specialties PrivateLimited, Mumbai, India) mounting reagent.

\section{Microscopy}

The length and width of rumen papillae were measured using an ocular micrometer attached with the Stereo Zoom microscope at $(5 \times 10 X)$ in thirty microscopic fields. Every fifth serial section was observed with a stereo zoom microscope. Double counting or measurement was avoided.

\section{Statistical analysis}

Data were represented as the mean \pm standard deviation(SD). All data were subjected to oneway ANOVA, and the significance of difference among means was determined using Duncan's multiple range test (DMRT). All analyses were conducted in "SAS/STAT version 9.1.3" for Windows Service Pack 4, 2004 SAS Institute, Cary NC USA for Windows. Differences at $P<0.05$ were considered statistically significant.

\section{Results}

\section{Live weight gain of kids}

There were no significant differences in initial live. After feeding milk replacer there were no significant differences in total live weight gain among the three groups. Total live weight gain of control and the soymilk groups (25\% and $50 \%$ soymilk) were $2.72 \pm 0.15,2.94 \pm 0.64$ and 2.96 $\pm 0.10 \mathrm{~kg}$, respectively. Figure 1shows pattern of live weight change of three groups of kids over the course of the experiment. There were no differences $(P>0.05)$ in daily and weekly live weight changes among three groups. These results in live weight changes reflected the final live weight of the kids. Final live weight of these three groups of kids also did not differ $(P>$ 0.05). 
Table 2. Effects of whole milk and rice-gruel based milk replacer fed to kids on blood components $($ mean \pm SD)

\begin{tabular}{|c|c|c|c|c|}
\hline \multirow{2}{*}{\multicolumn{2}{|c|}{ Blood variates }} & \multicolumn{3}{|c|}{ Dietary treatments } \\
\hline & & $100 \%$ Whole milk & $\begin{array}{l}75 \% \text { whole milk+ } \\
25 \% \text { milk replacer }\end{array}$ & $\begin{array}{l}50 \% \text { whole milk+ } \\
50 \% \text { milk replacer }\end{array}$ \\
\hline \multirow{2}{*}{\multicolumn{2}{|c|}{$\begin{array}{l}\mathrm{RBC}\left(\mathrm{m} / \mathrm{mm}^{3}\right) \\
\mathrm{WBC}\left(\mathrm{th} / \mathrm{mm}^{3}\right)\end{array}$}} & $9.19 \pm 0.04$ & $9.85 \pm 0.55$ & $9.4 \pm 0.38$ \\
\hline & $\left./ \mathrm{mm}^{3}\right)$ & $6.63 \pm 0.59$ & $6.63 \pm 0.52$ & $6.74 \pm 0.36$ \\
\hline \multirow{7}{*}{ 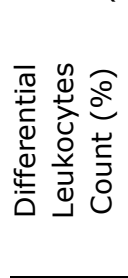 } & $\mathrm{Hb}(\mathrm{g})$ & $6.83 \pm 0.51$ & $7.27 \pm 0.37$ & $7.25 \pm 0.44$ \\
\hline & PCV $(\%)$ & $26.50^{b} \pm 1.29$ & $28.75^{\mathrm{a}} \pm 1.50$ & $27.25^{\mathrm{ab}} \pm 0.95$ \\
\hline & Neutrophil (\%) & $26.0 \pm 2.16$ & $24.5 \pm 2.08$ & $26.5 \pm 2.08$ \\
\hline & Eosinophil (\%) & $2.75 \pm 0.96$ & $2.75 \pm 0.5$ & $3.0 \pm 0.82$ \\
\hline & Basophil (\%) & 0 & 0 & 0 \\
\hline & Lymphocyte (\%) & $65.25 \pm 6.24$ & $69.25 \pm 3.59$ & $68 \pm 1.41$ \\
\hline & Monocyte (\%) & $2.5 \pm 1.00$ & $3.25 \pm 1.50$ & $2.5 \pm 0.58$ \\
\hline
\end{tabular}

Within a row, means with uncommon superscripts differ significantly $(P<0.05)$.

Table 3. Effects of feeding rice-gruel based milk replacer to kids on pre-slaughter body measurements (mean \pm SD)

\begin{tabular}{|c|c|c|c|c|}
\hline \multirow{2}{*}{\multicolumn{2}{|c|}{ Parameters }} & \multicolumn{3}{|c|}{ Dietary treatments } \\
\hline & & $100 \%$ Whole milk & $\begin{array}{l}75 \% \text { whole milk+ } \\
25 \% \text { milk replacer }\end{array}$ & $\begin{array}{l}50 \% \text { whole milk+ } 50 \% \\
\text { milk replacer }\end{array}$ \\
\hline \multicolumn{2}{|c|}{ Body length $(\mathrm{cm})$} & $37.3 \pm 8.2$ & $41.3 \pm 2.56$ & $39.75 \pm 1.80$ \\
\hline \multicolumn{2}{|c|}{ Wither height $(\mathrm{cm})$} & $32.85 \pm 3.92$ & $35.68 \pm 0.50$ & $32.25 \pm 1.30$ \\
\hline \multicolumn{2}{|c|}{ Heart girth $(\mathrm{cm})$} & $34.33 \pm 3.6$ & $37.9 \pm 1.92$ & $36.18 \pm 0.83$ \\
\hline \multirow{3}{*}{ 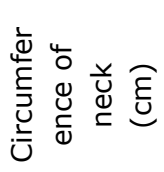 } & Apex & $15.9 \pm 3.32$ & $17.95 \pm 1.31$ & $17.58 \pm 1.65$ \\
\hline & Middle & $18.83 \pm 1.73$ & $18.53 \pm 0.77$ & $18.28 \pm 1.21$ \\
\hline & Base & $18.2 \pm 3.51$ & $20.2 \pm 1.01$ & $21.28 \pm 2.27$ \\
\hline \multicolumn{2}{|c|}{ Neck length $(\mathrm{cm})$} & $10.0 \pm 2.68$ & $12.45 \pm 0.5$ & $12.13 \pm 0.94$ \\
\hline
\end{tabular}

Table 4. Effects of feeding rice-gruel based milk replacer on carcass yield characteristics of kids (mean $\pm \mathrm{SD})$

\begin{tabular}{lccc}
\hline & \multicolumn{3}{c}{ Dietary treatments } \\
\cline { 2 - 4 } Parameters & $\mathbf{1 0 0 \%}$ Whole milk & $\begin{array}{l}\mathbf{7 5 \%} \text { whole milk+ } \\
\mathbf{2 5 \%} \text { milk replacer }\end{array}$ & $\begin{array}{c}\mathbf{5 0 \%} \text { who milk replacer } \\
\mathbf{5 0} \%\end{array}$ \\
\hline Carcass weight $(\mathrm{kg})$ & $1.65 \pm 0.60$ & $1.69 \pm 0.18$ & $1.70 \pm 0.28$ \\
Dressing Percentages*(\%) & $40.51 \pm 4.03$ & $40.88 \pm 1.29$ & $40.28 \pm 1.48$ \\
Caul fat $(\mathrm{g})$ & $13.0^{\mathrm{b}} \pm 2.16$ & $19.75^{\mathrm{a}} \pm 1.71$ & $17.5^{\mathrm{a}} \pm 2.52$ \\
Renal fat $(\mathrm{g})$ & $8.25 \pm 2.63$ & $12.0 \pm 1.83$ & $10.75 \pm 2.50$ \\
\hline
\end{tabular}

${ }^{\circ}$ Dressing percentages (calculated as hot carcass weight / live weight) $\times 100$ ). Within a row, means with uncommon superscripts differ significantly $(P<0.05)$. 
Table 5. Effects of feeding rice-gruel based milk replacer on non-edible by-products of kids (mean \pm SD)

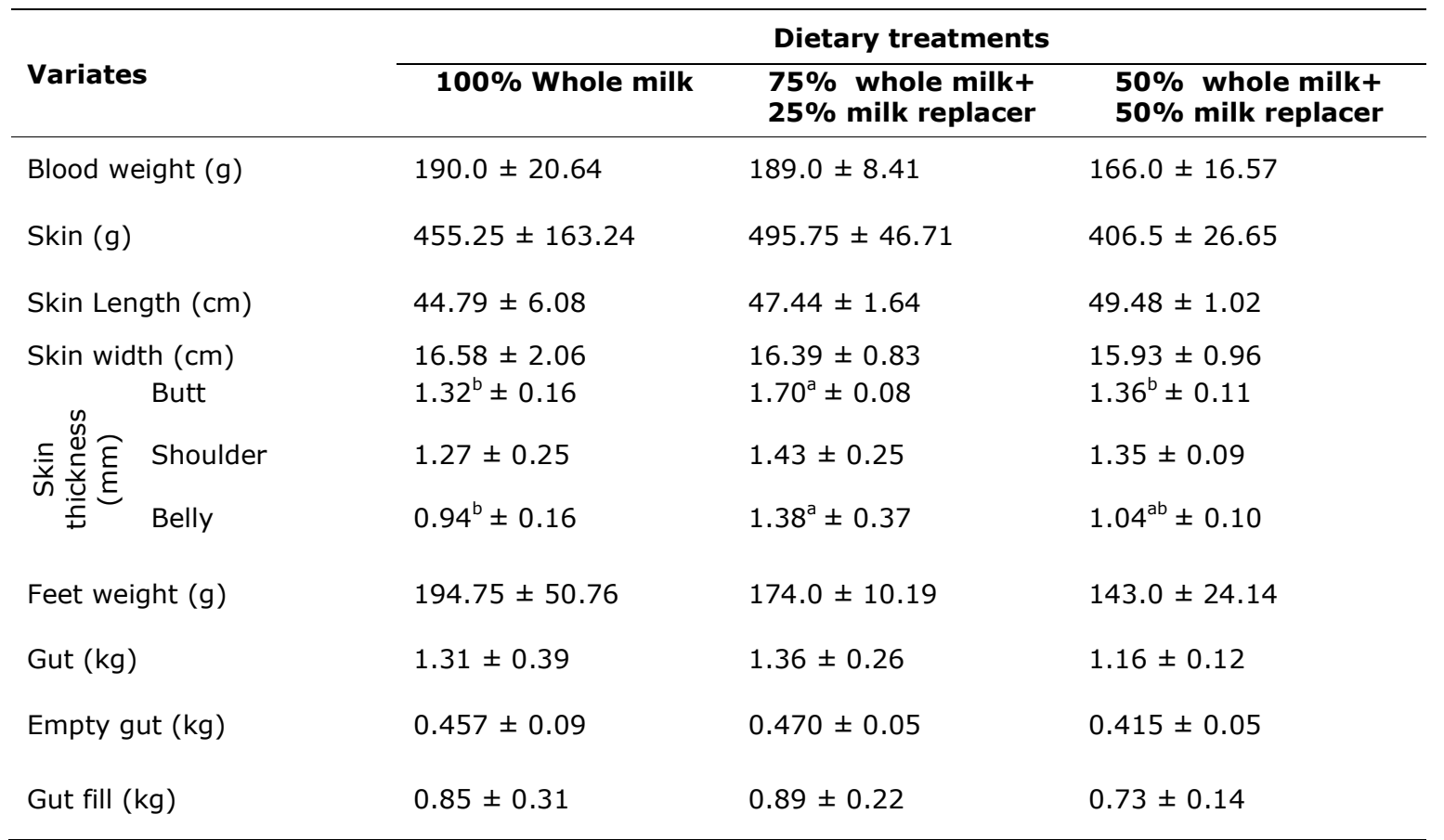

Within a row, means with uncommon superscripts differ significantly $(P<0.05)$.

Table 6. Effects of feedingrice-gruel based milk replacer on the edible by-products of kids (mean \pm SD)

\begin{tabular}{lccc}
\hline & & Dietary treatments \\
\cline { 2 - 4 } Variates & $\mathbf{1 0 0 \%}$ Whole milk & $\begin{array}{c}\mathbf{7 5 \%} \text { whole milk+ } \\
\text { 25\% milk replacer }\end{array}$ & $\begin{array}{c}\mathbf{5 0 \%} \text { 50\% milk replacer } \\
\text { 50\% }\end{array}$ \\
\hline Head $(\mathrm{g})$ & & $411.5 \pm 26.70$ & $350.00 \pm 44.66$ \\
Heart $(\mathrm{g})$ & $379.75 \pm 110.98$ & $25.00 \pm 2.58$ & $18.50 \pm 3.78$ \\
Spleen $(\mathrm{g})$ & $22.00 \pm 5.59$ & $15.75 \pm 1.26$ & $13.50 \pm 4.12$ \\
Liver $(\mathrm{g})$ & $12.75 \pm 4.99$ & $119.00 \pm 20.94$ & $104.50 \pm 21.99$ \\
Kidney $(\mathrm{g})$ & $106.00 \pm 23.04$ & $27.00 \pm 6.22$ & $22.00 \pm 2.83$ \\
Lung+ Trachea $(\mathrm{g})$ & $26.75 \pm 6.50$ & $66.50 \pm 5.51$ & $55.50 \pm 13.89$ \\
Pluck $(\mathrm{g})$ & $70.50 \pm 12.79$ & $258.33^{\mathrm{b}} \pm 14.13$ & $323.33^{\mathrm{a}} \pm 21.07$ \\
\hline
\end{tabular}

Within a row, means with uncommon superscripts differ significantly $(P<0.05)$

Table 7. Effects of feeding rice-gruel based milk replacer to kids on chemical composition of meat $($ mean \pm SD)

\begin{tabular}{lccc}
\hline & \multicolumn{3}{c}{ Chemical composition of meat } \\
\cline { 2 - 4 } Variates(\%) & $\begin{array}{c}\mathbf{1 0 0 \%} \text { Whole } \\
\text { milk }\end{array}$ & $\begin{array}{c}\mathbf{7 5 \%} \text { whole milk+ } \\
\mathbf{2 5 \%} \text { milk replacer }\end{array}$ & $\begin{array}{c}\mathbf{5 0 \%} \text { whole milk+ } \\
\mathbf{5 0 \%} \text { milk replacer }\end{array}$ \\
\hline Dry matter (DM) & $22.47^{\mathrm{b}} \pm 0.92$ & $24.72^{\mathrm{ab}} \pm 1.50$ & $26.67^{\mathrm{a}} \pm 3.33$ \\
Organic matter (OM) & $97.15 \pm 0.85$ & $97.24 \pm 0.29$ & $96.89 \pm 0.23$ \\
Crude Protein (CP) & $22.20 \pm 2.08$ & $24.34 \pm 1.94$ & $24.47 \pm 0.58$ \\
Ether Extract (EE) & $1.80^{\mathrm{b}} \pm 0.04$ & $2.16^{\mathrm{a}} \pm 0.21$ & $1.97^{\mathrm{ab}} \pm 0.06$ \\
Ash & $2.23^{\mathrm{b}} \pm 0.18$ & $2.82^{\mathrm{a}} \pm 0.15$ & $3.02^{\mathrm{a}} \pm 0.15$ \\
\hline
\end{tabular}

Within a row, means with uncommon superscripts differ significantly $(P<0.05)$. 


\section{Changes in blood components}

Table 2 shows that red blood cell (RBC), white blood cell (WBC), hemoglobin $(\mathrm{Hb})$ and differential leucocyte count (DLC)counts did not differ $(P>0.05)$ among the feeding groups. Packed cell volume (PCV) percentages was higher $(P<0.05)$ in $25 \%$ rice-gruel fed kids than whole milk offered counterparts.

\section{Pre-slaughter body measurements}

In the present study, body length $(B L)$, wither height $(\mathrm{WH})$, heart girth(HG), circumferences of neck at the position of apex, middle and base and neck length(NL) at the time of slaughtering did not differ $(P>0.05)$ among different treatment groups (Table $\mathbf{3}$ ).

\section{Carcass and non-carcass variates}

The effects of feeding rice-gruel based milk replacer on carcass yield and dressing percentage of kids are shown in the Table 4. Carcass weights, dressing percentages (\%) and renal fat content did not differ $(P>0.05)$ among the groups of kids. Caul fat deposition was higher $(P<0.05)$ in milk replacer fed kids than whole milk offered group. Table 5 shows the effects of feeding ricegruel based milk replacer on non-edible byproducts of kids. Weights of blood, skin, feet and gut did not differ $(P>0.05)$ among the groups. Thicknesses of skin in belly and butt regions were higher in $25 \%$ milk replacer fed kids than others. Table 6 shows the weight of different edible organs of kids such as head, heart, spleen, liver, kidney, lungs and pluck of kids. Only the weight of pluck was higher in $50 \%$ milk replacer fed kids than others while other variates did not differ $(P>0.05)$ among the groups.

\section{Chemical composition of meat}

The effects of feeding rice-gruel based milk replacer on dry matter (DM), organic matter $(\mathrm{OM})$, crude protein $(\mathrm{CP})$, ether extract $(\mathrm{EE})$ and ash content of meat are shown in the Table 7. Percentages of DM, EE and ash were higher $(P<0.05)$ in milk replacer fed kids than in the whole milk offered group although increasing the proportion of milk replacer did not result in significant change in these variates.

Table 8. Effects of feeding rice gruel based milk replacer on weights of rumen, reticulum, omasum and abomasum of kids (mean \pm SD)

\begin{tabular}{llll}
\hline \multirow{2}{*}{ Parameters } & \multicolumn{3}{c}{ Dietary treatments } \\
\cline { 2 - 4 } & $\mathbf{1 0 0 \%}$ Whole milk & $\begin{array}{l}\mathbf{7 5 \%} \text { whole milk+ } \\
\mathbf{2 5 \%} \text { milk replacer }\end{array}$ & $\begin{array}{l}\mathbf{5 0 \%} \text { whole milk+ } \\
\mathbf{5 0} \text { milk replacer }\end{array}$ \\
\hline Rumen $(\mathrm{g})$ & $119.74^{\mathrm{b}} \pm 26.98$ & $136.14^{\mathrm{ab}} \pm 23.91$ & $149.64^{\mathrm{a}} \pm 31.05$ \\
Reticulum $(\mathrm{g})$ & $23.38 \pm 5.82$ & $18.70 \pm 5.76$ & $26.92 \pm 4.00$ \\
Omasum $(\mathrm{g})$ & $12.94 \pm 4.64$ & $10.32 \pm 2.90$ & $15.00 \pm 2.08$ \\
Abomasum $(\mathrm{g})$ & $29.55 \pm 8.88$ & $27.16 \pm 3.33$ & $32.77 \pm 7.13$ \\
\hline
\end{tabular}

Within a row, means with uncommon superscripts differ significantly $(P<0.05)$.

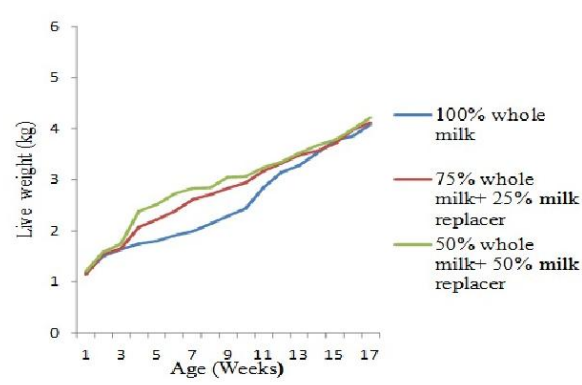

Figure 1. Cumulative growth of kids
$100 \%$ Whole milk
$75 \%$ whole milk + $25 \%$ milk replacer
$50 \%$ whole milk + $50 \%$ milk replacer

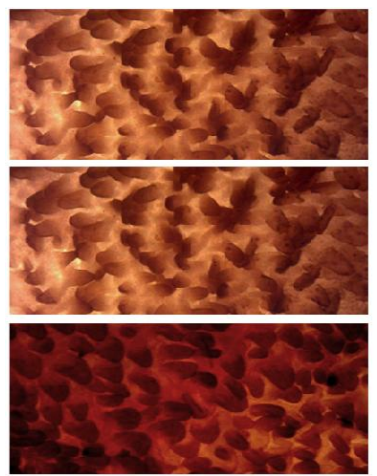

Figure 2. Density of rumen papillae under light microscope $(5 \times 10 \mathrm{X})$ 


\section{Rumen development}

In the present study, rumen weights were significantly higher $(P<0.05)$ in $50 \%$ milk replacer offered goats than $100 \%$ milk treated group. Lowest rumen weight was recorded in whole milk fed kids. The weight of reticulum, omasum and abomasum did not differ $(P>0.05)$ among the different dietary treatment groups. Rumen wall thicknesses were higher $(P<0.05)$ in $50 \%$ milk replacer feeding group than others and the thicknesses increased as the proportion of milk replacer in the diet increased (Table 9). The thickness $(\mathrm{mm})$ at the left side ventral portion of caudal ventral blind sac (LE) and left side of cranial dorsal sac (LC) position did not differ
( $P>0.05$ ) among the treatment groups (Table 9).Kids offered $50 \%$ rice-gruel milk had the thickest rumen wall at theright side ventral portion of caudal ventral blind sac (RE). Densities of rumen papillae per microscopic field were higher $(P<0.05)$ in $50 \%$ milk replacer feeding group than whole milk fed kids(Table $\mathbf{1 0}$ and Fig. 2). The density of papillae increased with the increase of the proportion of rice-gruel in the diet. Histological examination revealed that length and width of papillae were higher $(P<0.05)$ in milk replacer fed kids than whole milk fed counterparts (Table $\mathbf{1 0}$ and Fig. 3). The whole milk treatment had the narrowest papillae and the $50 \%$ rice-gruel milk treatment had the widest papillae.

Table 9. Effects of feeding rice-gruel based milk replacer on rumen wall thickness of kids (mean \pm SD)

\begin{tabular}{|c|c|c|c|}
\hline \multirow[b]{2}{*}{$\begin{array}{l}\text { Location in } \\
\text { rumen }\end{array}$} & \multicolumn{3}{|c|}{ Rumen wall thickness (mm) } \\
\hline & $100 \%$ Whole milk & $\begin{array}{l}75 \% \text { whole milk+ } \\
25 \% \text { milk replacer }\end{array}$ & $\begin{array}{l}50 \% \text { whole milk+ } \\
50 \% \text { milk replacer }\end{array}$ \\
\hline RD & $1.49^{\mathrm{b}} \pm 0.42$ & $2.49^{\mathrm{a}} \pm 0.65$ & $2.87^{\mathrm{a}} \pm 0.16$ \\
\hline LD & $1.48^{\mathrm{b}} \pm 0.39$ & $2.37^{\mathrm{a}} \pm 0.50$ & $2.67^{\mathrm{a}} \pm 0.22$ \\
\hline $\mathrm{RC}$ & $1.48^{\mathrm{c}} \pm 0.5$ & $2.33^{\mathrm{b}} \pm 0.26$ & $2.94^{\mathrm{a}} \pm 0.18$ \\
\hline RB & $1.39^{\mathrm{b}} \pm 0.36$ & $2.09^{a} \pm 0.44$ & $2.14^{\mathrm{a}} \pm 0.35$ \\
\hline RE & $1.91^{b} \pm 0.92$ & $3.07^{\mathrm{a}} \pm 0.55$ & $3.40^{\mathrm{a}} \pm 0.33$ \\
\hline LE & $1.72 \pm 0.96$ & $2.03 \pm 0.10$ & $2.67 \pm 0.36$ \\
\hline LC & $2.48 \pm 0.85$ & $2.69 \pm 0.31$ & $3.20 \pm 0.52$ \\
\hline LB & $1.97^{\mathrm{b}} \pm 0.68$ & $2.53^{\mathrm{ab}} \pm 0.45$ & $3.10^{\mathrm{a}} \pm 0.35$ \\
\hline A & $1.52^{\mathrm{b}} \pm 0.54$ & $2.06^{\mathrm{ab}} \pm 0.54$ & $2.46^{\mathrm{a}} \pm 0.19$ \\
\hline
\end{tabular}

${ }^{* *}$ Right side of cranial ventral sac (RD), Left side of cranial ventral sac (LD), Right side of cranial dorsal sac $(R C)$, Right side of caudal dorsal sac (RB), Right side ventral portion of caudal ventral blind sac (RE), Left side ventral portion of caudal ventral blind sac (LE), Left side of cranial dorsal sac (LC), Left side of caudal dorsal sac (LB), Caudal portion of the caudal ventral blind sac (A).

Within a row, means with uncommon superscripts differ significantly $(P<0.05)$.

Table 10. Effects of feeding rice-gruel based milk replacer on rumen development of kids (mean \pm SD)

\begin{tabular}{|c|c|c|c|}
\hline \multirow[b]{2}{*}{ Variates } & \multicolumn{3}{|c|}{ Dietary treatments } \\
\hline & $100 \%$ Whole milk & $\begin{array}{l}75 \% \text { whole milk+ } \\
25 \% \text { milk } \\
\text { replacer }\end{array}$ & $\begin{array}{l}50 \% \text { whole } \\
\text { milk+ } \\
50 \% \text { milk } \\
\text { replacer } \\
\end{array}$ \\
\hline Papillae length ( $\mu \mathrm{m}, 5 \times 10 \mathrm{X})$ & $475.15^{b} \pm 10.03$ & $489.46^{\mathrm{ab}} \pm 7.76$ & $514.05^{\mathrm{a}} \pm 21.15$ \\
\hline Papillae width $(\mu \mathrm{m}, 5 \times 10 \mathrm{X})$ & $51.25^{\mathrm{b}} \pm 1.76$ & $52.22^{\mathrm{ab}} \pm 2.43$ & $60.0^{\mathrm{a}} \pm 6.88$ \\
\hline Papillae density (no/ob., $5 \times 10 \mathrm{X}$ ) & $17.22^{\mathrm{b}} \pm 1.30$ & $18.50^{\mathrm{b}} \pm 1.29$ & $25.0^{\mathrm{a}} \pm 2.45$ \\
\hline
\end{tabular}

Within a row, means with uncommon superscripts differ significantly $(P<0.05)$. 


\section{Discussion}

In our previous study, Black Bengal goat kids were artificially reared with whole milk and soybean based milk replacers to elucidate the effects of soymilk based milk replacer on the performance of kids including weight gain, blood parameters and development of rumen and gonads(Sarker et al., 2015). We showed that whole milk could be replaced by soymilk up to $50 \%$ without significant differences in growth, carcass characteristics, rumen and gonad development. In the present study, milk replacers were prepared by dissolving soy flour in rice gruel instead of water. Since rice gruel contains enormous amount of soluble carbohydrates and vitamins, it has been offered to domestic ruminants in south Asian countries. Hasanuzzaman et al. (2014) reported that rice gruel is comparable to molasses as a source of energy for cattle. In the current study, we found that growth of kids in terms of live weight gain and pre-slaughter body measurements did not show any significant change due to feeding milk replacers. The reason for this similarity in live weight gain is not understood well. It may be due to the similarity in composition of milk and milk replacers used in this experiment. In another study be Ghorbani et al. (2007) showed that feeding milk replacer ( $25 \%$ and $50 \%$ soymilk) in combination of whole milk did not have any effect on weight gain of kids (Ghorbani et al., 2007).

In the present study, earlier rumen development was recorded in milk replacer consumed kids than whole milk fed ones. It might possible that intake of fibrous particles of plant origin available in soymilk stimulated the earlier rumen development in kids. It has been reported that feeding only milk causes delayed initiation of ruminal fermentation and development in calves because of depressed intake of solid feed (Quigley et al., 2006).Calves fed solid feeds showed higher rumen volume and papillary growth than only milk received ones (Warner et al., 1956). We found that density of rumen papillae per microscopic field was higher $(P<0.05)$ in kids fed $50 \%$ milk replacer which resulted in the higher absorptive surface of rumen and earlier rumen development. Rumen thicknesses at different positions were $(P<0.05)$ higher in 50\% milk replacer group than others. This result is in good agreement with our previous study where it was found that soybean enhanced rumen development in kids (Sarker et al., 2015).Rumen papillae length and width, rumen wall thickness, and papillae density is influenced by dietary factors (Harrison et al., 1960; Tamate et al., 1962). Fibrous feedstuffs encourage rumen development and appear to speed up the development of the rumen wall muscles (Morand-Fehr et al., 1982).

Haematological changes are routinely used to determine the various influences of nutritional factor (Garacyk et al., 2003). WBC is known to play key roles in immune defense system of animals (Eheba et al., 2008). The present study showed that RBC, WBC, Hb, DLC (neutrophil, eosinophil, basophil, lymphocyte and monocyte) percentages did not differ significantly among the groups. This indicated that milk replacers provided sufficient nutrients to support the immune system of kids. The higher level of PCV was found due to increased level of milk replacer consumption in kids. Packed cell volume (PCV) and haemoglobin reflected the nutritional status of the animal (Etim et al., 2014). Isaac et al. (2013) reported that PCV is involved in transport of oxygen and absorbed nutrient. Previously it was reported that $\mathrm{Hb}$ level of kids increased in milk replacer fed kids than the whole milk fed counterparts (Sarker et al. 2015). In the present study, $\mathrm{Hb}$ values did not differ significantly among the groups although the values were higher in milk replacer fed kids.

In the present study, dressing percentages, carcass weight and weights of different edible and non-edible products and by-products did not differ among the groups. These data revealed that milk replacer fed kids grow up with normal physiology and balanced organ development. Higher amount of caul fat and EE values in milk replacer fed kids indicated the higher deposition of fat in their body. Other components such as proportion of ash was also higher in milk replacer feeding kids. These may be the result of consuming the high content of carbohydrates, vitamins and minerals available in rice-gruel.

\section{Conclusion}

Rice gruel based milk replacer in combination of whole milk can be used for profitable rearing of kids. Thus, neonatal kids may be reared artificially byreplacing whole milk with rice-gruel milk up to $50 \%$ without any detrimental effects on their growth, blood parameters, carcass characteristics and rumen development. The present study suggested that rice gruel can be considered a potential ingredient when preparing milk replacer for goat kids. 


\section{Conflict of interest}

The authors declare that there is no conflict of interest that could be perceived as prejudicing the impartiality of the research submitted.

\section{Acknowledgements}

This research was funded by the Ministry of Science and Technology, Government of the People's Republic of Bangladesh. We are thankful to Dr. Steve Clark, Senior Research Scientist, Agriculture Research \& Development, Department of Economic Development, Jobs, Transport and Resources, 915 Mt. Napier Road, Private Bag 105, Hamilton, Victoria 3300, Australia, for his critical suggestions for improvement of this manuscript.

\section{References}

Aggarwala AC, Sharma RM (1961). A laboratory manual of milk inspection (4th edition), Asia Publishing House, Bombay, Calcutta, New Delhi, India.

Akinyele IO, Harshbarger KE (1983). Performance of young calves fed soybean protein replacers. Journal of Dairy Science, 66: 825-832.

AOAC. Official methods of analysis 1984, (14th edition), Association of Official Analytical Chemists, Washington, DC, USA.

Eheba ETE, Omoikhojie SO, Bangbose AM, Duruna MB, Isidhahomen CE (2008). Haematology and serum biochemistry of weaner rabbits fed cooked bambara groundnut meal as replacement for soybeans meal. Proc. of 33rd Annual Conference of Nigerian Society for Animal Production, pp. 192-196.

Etim NN, Enyenihi GE, Akpabio U, Offiong EEA (2014). Effects of nutrition on haematology of rabbits: a review. European Scientific Journal. 10: 413-424.

FAO (1999/4). Poverty alleviation and food security in Asia - Role of Livestock. RAP publication.

Garacyk S, Pliszozackrol A, Kotonski B, Wilczek J, Chimelak Z (2003). Examination of haematological and metabolic changes mechanism of acute stress in turkeys. Electronic Journal of Polish Agricultural Universities, 6: 110.

Ghorbani GR, Kowsar R, Alikhani M, Nikkhah A (2007). Soymilk as a novel milk replacer to stimulate early calf starter intake and reduce weaning age and costs. Journal of Dairy Science, 90: 5692-5697.

Harrison HN, Warner RG, Sander EG, Loosli JK (1960). Changes in the tissue and volume of the stomachs ofcalves following the removal of dry feed or consumption of inert bulk. Journal of Dairy Science, 43: 1301-1312.
Hasanuzzaman M, Akter N, Begum MR, Alam M, Yeasmin T, Sarker MS (2014). Study on effect of rice gruel on growth performance of cattle. Journal of Animal Science, 14: 1051-1058.

Iheukwumere FC, Herbert U. Physiological responses of broiler chickens to quantitative water restrictions: Haematology and serum biochemistry. Journal of Poultry Science, 2:117119.

Isaac LJ, Abah G, Akpan B, Ekaette IU (2013). Haematological properties of different breeds and sexes of rabbits. In 'Proc. of the 18th Annual Conference of Animal Science Association of Nigeria, pp. 24-27.

Lesmeister KE, Tozer PR, Heinrichs AJ (2004). Development and analysis of a rumen tissue sampling procedure. Journal of Dairy Science ,87: 1336-1344.

Morand-Fehr P, Hervieu J, Bas P, Sauvant D. Feeding of young goats (1982). In: Proc. 3rd Int. Conf. Goat Production and Diseases. Tucson, AZ, pp. 90-104.

Oyawoye BM, Ogunkunle HN (2004). Biochemical and haematological reference values in normal experimental animals. Masson, New York, 212-218.

Quigley JD, Caldwell LA, Sinks GD, Heitmann RN(1991). Changes in blood glucose, nonesterified fatty acids, andketones in response to weaning and feed intake in young calves. Journal of Dairy Science74: 250-257.

Quigley JD, Wolfe TA, Elsasser TH (2006). Effects of additional milk replacer feeding on calf health, growth, and selected blood metabolites in calves. Journal of Dairy Science,89: 207-216.

Sarker MB, Alam MH, Saha BK, Amin MR, Moniruzzaman M (2015). Effects of soybean milk replacer on growth, meat quality, rumen and gonad development of goats. Small Ruminant Research, 130: 127-135.

SAS Institute Inc.(2004) Base SAS/STAT version 9.1.3 for windows service pack 4, SAS Institute, Cary NC, USA.

Sato T, Hidaka K, Mishima T, Nibe K, Kitahara G, Hidaka $Y$, Katamoto $H$, Kamimura S(2010). Effect of sugar supplementation onrumen protozoa profile and papillae development in retarded growth calves. Journal of Veterinary Medicine and Science, 72: 1471-1474.

Suresh R, Balakrishnan V, Vasan P (2016). A survey on feeding pattern of rice gruel among the farmers of north eastern agroclimaticzone of Tamil Nadu. International Journal of Science and Environment, 5: 2566-2569. 
Swenson MJ (1970). Physiological properties, cellularand chemical constituents of blood. In 'Dukes Physiology of Domestic Animals'(Ed. MJ Swenson) pp.75-83. (Cornstock Publishing Associates, Cornell University Press, Ithaca, London, UK).

Tamate $H$, McGilliard AD, Jacobson NL, Getty R (1962). Effect of various dietaries on the anatomical development of the stomach in the calf. Journal of Dairy Science, 45: 408420.
Terui H, Morrill JL, Higgens JJ (1996). Evaluation of wheat gluten in milk replacer and calf starter. Journal of Dairy Science,79: 12611266.

Warner RG, Flatt WP, Loosli JK(1956). Dietary factors influencing the development of the ruminant stomach. Journal of Agricultural and Food Chemistry, 4: 788-801. 